DOI: http://doi.org/10.22364/ruslat.glp.01

Наталья Вершинина

\title{
«Рижский текст» в путевом очерке Ф.В. Булгарина «Поездка из Лифляндии в Самогитию, через Курляндию, летом 1829 года (письмо к Гречу)»
}

В статье рассматривается специфика «рижского текста» в малоисследованном сочинении Ф.В. Бумгарина «ПоезАка из АифмянАии в Самогитию, через КурмянАию, метом 1829 года (Письмо к Гречу)». Анализируется своеобразие «путевых заметок» писатемя как многофункционального жанрово-стилевого образования. Аелается вывод о наличии «механизма» (В. Топоров), способствующего выделению в «путешествии» Булгарина «рижского текста». На структурно-семантическом уровне в нем реализуется мысль писателя о благотворном воздействии просвещения на Ауховную и материальную стороны жизни «балтийской столицы».

Ключевые слова: Рига, «рижский текст», «литературное путешествие», читатель, культура повсеАневности, жанровая традиция

«ПоезАКа из АифмянАии в Самогитию, чрез КурлянАию, метом 1829 года (Письмо к Гречу) Ф ФаАлея Булгарина, напечатанная в четырех номерах газеты «Северная пчела» за 1829 гоА, Ао сих пор принадлежит к числу мамоисследованных. Представляется, что основанием может быть не только негативный отпечаток, который несет на себе репутация Бумгарина, можно преАположить, что причиной является и собственно митературный показатель: жанрово-стилевая «неопределенность» его «путешествий», их выпадение из принятой митературоведением типологии. Исследователи этой формы, в том числе и позАнейшие: В.А. Михайлов (Михайлов 1999), И.В. Банах (Банах 2004), Н.Ф. Иванова (Иванова 2010) - могли испытывать затруАнения относительно присоеАинения путевых заметок Булгарина к Авум известным разновианостям: географическому, «объективному», «ре-

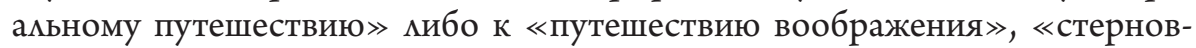
ской» ветви жанра, гАе «настоящего описания путешествия, в сущности, нет» (Роболи 1926: 48). И то и Аругое, по меркам традиционных митературоведческих классификаций, преАполагает элемент эстетизации, имеющий хоть и разный кумьтурный генезис, но одинаково значимый в плане поАхоАа к произведениям с позиций стилистики и поэтики.

Что касается путевых заметок Булгарина, то они словно бы демонстрирует отторжение от каких-либо требований эстетики. Термин «гибриАный» по отношению к Аанному жанру реализуется автором буквально 
(можно преАположить, не без огмядки на Н.М. Карамзина - автора «Писем русского путешественника») - как смешение разнородных стияевых и интонационных планов, описаний увиденного воочию и почерпнутого из книжных источников, статистических и историко-экономических сведений и пространных авторских отступлений, создающих «имАюзию $<\ldots>$ интимности» (Роболи 1926: 44).

Изучение структуры «литературных путешествий» Бумгарина свидетельствует об устойчивой устремленности автора не в сторону эстетики, а в область китературного быта. Очевидно, Булгарин ценил в «путешествиях», прежде всего, их коммуникативную, посредническую функцию. Это означало, что он, с одной стороны, приподымац публику наА привычной обыденностью, а, с Аругой - Аавац понять, что сознает условность расстояния межАу собой и ею и всегАа готов вступить во внелитературные отношения, касающиеся проблем существенных: материальных, политических, моральных и ряда Аругих.

В собственной кмассификации Булгарина путешествия входили в обмасть литературы - об этом свидетельствует его письмо А.Ф. Орлову от 13 апремя 1845 г.: «Ао сих пор написано мною и издано в свет, по части словесности: 16-ть томов романов, 18 томов повестей, статей о нравах, биографий, разных исторических отрывков и путешествий, один том путешествия в Швецию <...> (Видок Фиглярин 1998: 472). При этом писатель иегко переводия «путешествие» во внелитературный контекст, о чем свидетельствуют его «записки» в III отделение.

Так, в агентурной записке, скопированной управмяющим III отАемением М.Я. Фоком, условно озаглавленной «О поездке Булгарина в Остзейские губернии», задачи, побудившие автора к «путешествию», изможены в следующем порядке: «1) Отвесть больную жену к морским водам <..> 2) Окончить фамильные Аела $<\ldots>3$ ) Отдохнуть от трудов механических по журнаку и рассеяться $<\ldots>4$ ) Оживить описанием путешествия свои журналы» (Видок Фиглярин 1998: 170). Результатом этой поездки, наряду с Аругими ее слеАствиями, Аействительно стала пространная «Прогулка по

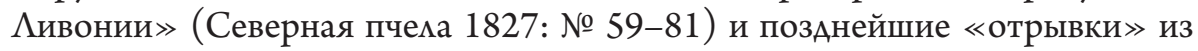
нее, публиковавшиеся в той же газете. Характеризуя этот текст, современный исследователь справеАливо отмечает Аанное в нем «историческое и этнографическое описание <...> региона» (Видок Фиглярин 1998: 170), что не отменяет общей установки Булгарина, цеми которого и здесь быми заведомо экиектичны, по-своему специфичны.

В русле нашей темы это означает, что возможно ввести в обихоА, применительно к «литературным путешествиям» Бумгарина, семиотическую категорию «текст»: как указывает В.Н. Топоров, говоря о Петербургском тексте, это «не просто усиливающее эффект зеркало города, но устройство, с помощью которого и совершается переход от реального к реальнейшему, пресуществление материальной реальности в Ауховные ценности», но при этом он «отчетливо сохраняет в себе следы своего внетекстового 
субстрата и в свою очередь требует от своего потребителя умения восстанавливать <...> связи с внеположенным тексту, внетекстовым Аля каждого узма Петербургского текста» (Топоров 1995: 259). Приведенное замечание касается не только Петербургского текста - как показывают исследования матвийских ученых, «рижский текст», в основание которого положена Рига, ее «образ и смысл» (Kursīte, Sproge, Cimdiña 2008: 8) содержит богатый и перспективный Аля Аальнейшего изучения материал.

Изначально Рига входила во внелитературный кругозор Булгарина - в 20-30-е годы он активно измагал в записках Аля III-го отАеления сужАения «о Аухе жителей Остзейских провинций и Аитвы» (ВиАок Фиглярин 1998: 178). По существу, зАесь выстраивался «первичный» «рижский текст», его «узАы», по выражению В.Н. Топорова. ОАновременно созАавался аналог митературного «рижского текста». Важнейшими «узмовыми» темами стали: гражданское общество, его состав и настроение разных слоев («чиновники и бюрократы», «высшие чиновники», «помещики», «часть жителей из купечества и Аворян»); состояние торговли (в том числе, книжной), правосуАия, просвещения; отношение к религии, госуАарю, российской госуАарственности (Видок Фиглярин 1998: 178-190).

Описание Риги, составмяющее не меньше половины материала, вошеАшего в его сочинение «ПоезАка из Аифмяндии в Самогитию, чрез Курмянаию, метом 1829 года (Письмо к Гречу) - это еще одна огласовка узнаваемых реалий, занимающих автора, увиденных словно бы с близкого расстояния, но при этом производящих «цельно-еАиное» (Топоров 1995: 261) впечатление сверхтекстовой структуры. «Рижский текст» оАновременно созАается и в соответствии с конкретным политическим и социально-экономическим содержанием момента (предмет внимания Булгарина), и с его неизменными универсальными составляющими, которые домжны вкАючить обозреваемый город не только в сферу общественных отношений, но и в историю существования человечества.

Представление Риги читателю начинается с конкретного эпизода - посещения путешественником «знаменитой» «Ивановской ярмарки, проАолжающейся три недели от Иванова Аня, т.е. от 24-го Июня». Рассказ вводит читателя в подробности обстановки этого Аейства: «В ограде кафеАрахьной церкви Аютеранского исповеАания (Dom), среАи города, устроены в несколько миний красивые балаганы, с Аовольно широкими перехоАами; кроме того, товары разложены по Алинным коридорам обширного зАания, бывшего некогАа Католическим монастырем, соеАиненного с церковью. Из ограды должно переходить в коридоры через самую церковь, которая всегАа отворена» (Булгарин 1829а). Аалее следует расширение «рижского текста» типичным Амя автора способом аналогий - как заметил Булгарин в Аругом своем путешествии: «Всё это может быmb, а гАе нет верного, там позволено Аогадываться и судить по аналогии» (Булгарин 1835). РассужАения путешественника не сухо публицистичны - скорее, они настраивают на тон душеполезной беседы: «Не вхожу в рассуждения 
прилично $и$ превращать храм божий в торжище, но помню, что Спаситель повелел удалиться торговцам за ограды храма иерусалимского, как то виАим из Евангелия. Это мысль родилась в голове моей в самом конце ярмарки, и я, осмотревшись кругом, вообразил, что на самом Аеле нахожусь в Иерусалиме».

Пиан авторских рассуждений, реализуемый во взаимодействии с наличной жизненной конкретикой, - принцип, межащий в основе организации «рижского текста», но у Булгарина «воображение» путешественника нереАко колеблет баланс объективного и субъективного: «Уиицы в городе Риге узкие и неправильные; Аомы высокие, никакой архитектуры; в кажАом почти доме мавка, а наА мавкою надпись или вывеска на Немецком и Еврейском языках; множество Евреев на улицах и в мавках, наконец, торжище возце храма и самый храм готический, необыкновенной высоты, - все это вместе сильно подействовало на мое воображение, которое перенесло меня в Аревность, на горы Сиона. Впрочем, все купеческие народы и города в Аревности и новые времена несколько похожи Аруг на Аруга. Аксиома: оАни причины произвоАят оАни послеАствия. Первая причина торговли выгода - послеАствия известны» (Булгарин 1829а).

Аанное замечание переводит бесеАу с читателем в новое русло - в план преАставлений о послеАствиях сугубо практических жизненных целей и понятий о выгоде не только Аля отАельного человека, но страны или города. «В торговых городах и народах обеА или бал входит в торговый баланс, и Аолжен принесть проценты; ссуда есть также роА оборота, который Аолжен Аоставить выгоды, хотя бы капитал пропац невозвратно. Привыкнув к расчету, человек делается сам машиною, и торговые города обыкновенно насемены подвижными счетами.

Музы никогаа не жили в Аружбе с Пиутусом и Меркурием. Тир и СиАон, а после Карфаген, славившиеся в Аревнем мире как первые торговые города, не произвели ни одного великого Писатемя и Художника».

Применяя эту закономерность к Риге, путешественник, следуя принятой могике, приходит к критической точке зрения: «Просвещенное Аворянство не мюбит жить в Риге, где належало бы состязаться с милмионщиками. Купеческая аристократия водится межАу собою чинно и церемониально. Чиновники знаются также межАу собою, и не имеют ни времени, ни средств предаваться наслаждениям. Все Авижение, вся жизнь в Риге есть впуск и выпуск товаров. Предмет разговоров: курс, цены и биржевые известия вообще. Есть исключения из правия, но их немного» (Бумгарин 1829a).

Несмотря на то, что набцюдения и выводы путешественника подаются читателю как его собственное, только что сделанное открытие, они «прочитываются» уже в границах «рижского текста», начамо которому было положено на рубеже XVIII-XIX веков (описания Риги Н. Крамзиным, Б. Пестелем (1798), О. Гуном (1804) и Ар.). Контуры «рижского текста», например, были намечены в работе Гуна «Топографическое описание 
города Риги с присовокуплением врачебных наблюдений». 3Аесь выделены опорные пункты «текста», которые позднее на свой каА «оживит» Букгарин. По поводу «отсутствия» писателей в Риге у Гуна, в частности, сказано: «ЗАесь не занимаются сочинением книг < ...>» (Гун 1804: 168).

Но у Гуна отсутствует риторика противопоставления Аруг Аругу словесности и торговми. У Букгарина этот прием, возможно, предполагает Авойной эффект: заостряющий уже указанный контраст и оАновременно позволяющий сказать, что Аалеко не чужАая путешественнику сфера практической деятельности, не рожАая гениев, способствует распространению просвещения в массах. Критическая аттестация, таким образом, обнаруживает внутри себя позитивную сторону. Закономерно преАположить: если задача бумгаринских путешествий не сводилась к сугубо митературной, то важнее Аля автора было показать, как просвещение влияет на повседневный быт, облагораживает его, рождает «пламенный патриотизм», воспитывая взамен «писателей» гуманных мюдей.

На свой маА следуя за Гуном, Булгарин созАает как бы «поверх» его сочинения свой «рижский текст». У Гуна: «< .. > в прочем однако ж Аостаточные Аюди знатного и среднего состояния, также знатные и просвещенные особы в городе почитают за честь иметь у себя библиотеки, в коих находятся Арагоценные собрания, касательно Иифмяндской истории и во-

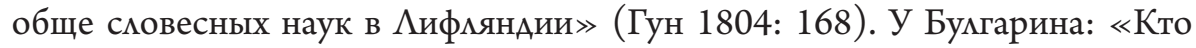
зАесь покупает Русские книги, которых и в самой России немного покупают? Чиновники Русские, офицеры, малое число Русских купцов и здешних Аворян, которые Аолго служили в России и привыкли к Русскому языку. Вообще Аворянство в Остзейских провинциях ныне весьма просвещенное, и если, по несчастию, большая часть не читает по-русски, то, по крайней мере, по переводам с Русского знает кучших наших Писателей. Случайно я познакомился с молодою девицею (фон Б... рг), которая из мюбви к Русскому языку изучилась оному, и читает все, что выходит у нас кучшего» (Букгарин 1829b).

Воспроизводя модель «рижского текста» с опорой на Гуна, Бумгарин перенимает и ее компоненты. Их составляют: умицы с присущей им теснотой и одновременно - опрятностью; полиция и ее радение порядку; благотворительные заведения, существующие на пожертвования граждан; наличие учебных заведений, в их чисме - университет; торговмя и соотносимый с этой областью комплекс экономических проблем; правосудие и «землеАельчество», Аоведенные, по мнению Букгарина, Ао «совершенства».

Вновь прибегая к риторическому ходу, путешественник заявмяет, что не будет описывать Ригу и тем самым привлекает внимание к объекту, вызывая реакцию читатемя и его правомерный вопрос - почему? «Я не стану описывать тебе, на этот раз, города Риги, существующего слишком 600 мет и знаменитого в Северной истории. ЗАесь весьма много Аревностей, Аостойных подробного описания; но Амя этого надобно более места, нежели сколько позволяют пределы письма с Аороги». Пробудив в читателе 
сожаление о несостоявшемся «путешествии», путешественник спешит развеять разочарование подробным рассказом о Риге:

«Местоположение города живописно со стороны обширной Авины. Большие корабли подходят с товарами к самому плавучему мосту, и, останавливаясь кормами по обеим сторонам оного, составмяют прелестнейшую в мире умицу на гибемьной стихии. ВиА с этого моста на город, на форштаты и в море - еАинственный. Аревний замок Иифмянаских Гермейстеров возвышается с своими башнями на берегу, и высокие шпицы готических храмов, возносящихся к небу из громады красных крышек, представцяют великолепное зрелище. С. Петербургский форштат, построенный вновь после сожжения оного, в 1812 году, есть почти особый город в новом вкусе, с широкими улицами и красивыми Аомами правильной архитектуры.

Нельзя Аовольно надивиться чистоте в городе Риге, при столь тесных улицах и Аомах без Аворов, или с такими Аворами, что еАва можно на них повернуться. Это Аолжно отнести столько же к чести Помиции, сколько и к опрятности жителей. Без больших и ежеАневных усилий почти невозможно было бы содержать в чистоте эту массу Аомов, построенных почти оАин на Аругом. Внутри еще чище, и хотя в убранстве Аомов нет такой роскоши, как в Петербурге, но чистота и прочность заменяют измишество, и мне горазАо более нравится.

$<\ldots>$ Ни в одном городе в целой Российской Империи, и вероятно ни в оАном в Европе, нет столько благотворительных заведений Аһя воспитания юношества, Аля призрения сирых и больных на счет города, как в Риге. Я имею описания сих заведений и исчисление сумм, пожертвованных городом и частными АюАьми на устройство и содержание оных. Великодушие купцов превосходит великое описание! < ..> В Риге возАвигнуты первые памятники Аля увековечивания славы, приобретенной Россией в Отечественную войну. Противу замка возАвигнута колонна с приличными надписями; в конце Петербургского форштата находятся прочные и красивые триумфальные ворота. <...> Все Аворяне и многие из купцов и среднего сословия служат Государю и Отечеству в военной и гражАанской службе, служат с честью и отлично. Большая часть из них прежАе кончат курс наук в Университете, или по крайней мере в высших учебных заведениях, и после уже поступают на службу».

Вывод сформулирован посредством аналогий, переходящих в перифраз: «Аерпт - есть Афины Аивонии, Рига - Карфаген Аивонского мира, Ревель - Спарта, Эстлянцы почти все воины по Ауху и воспитанию» (Булгарин 1829b).

В заключение отметим, что Булгарин, как бы межАу прочим, называет жанр своего сочинения - «письмо с дороги». Если эпистолярная форма, культивированная митературой XVIII века, была окружена эстетическим 
ореолом, что учитывалось автором, то прибавление «с Аороги» выводило ее из митературы в житейский план. На грани митературы и быта правомерно воспринимать и «митературные путешествия» Булгарина. Значение «рижского текста», преАставленного в разбираемом сочинении, не в Аостоверности - чтобы судить о ней (как это делает, путем анализа, А.Н. Николаевна Киселева относительно «Прогулки по Аивонии» Булгарина (Киселева 2006)), необходимо специальное исследование историко-краевеАческого характера. ВряА ми можно вести речь и об известных митературных Аостоинствах Аанного сочинения, исходя из того, что к белметризации путевых заметок не стремился и сам Булгарин. По нашему мнению, ценность Аанного сочинения - в закреплении уже имевшего место в труаах историков и митераторов образа Риги через свеАение воеАино опреАеляющих его бытовых и символических признаков. ПреАставление этих свойств как бы в Авойном освещении - сквозь присущую многим и принаАлежащую только путешественнику призмы созерцания действительности - формирует понятие «рижский текст», отвечающее запросам эпохи и ее преАставителей, среАи которых «привыкший к туризму» Булгарин (Рейтблат 2016: 399).

\section{Литература}

Банах, И.В. (2010). Нарративнал структура жанра путешествия (на материале русской митературы конца XVIII - первой трети XIX вв. Автореф. Аис. < ...> канА. филол. наук. Минск. 24 с.

Булгарин, Ф.В. (1829а). ПоезАка из Аифмяндии в Самогитию, чрез Курляндию, метом 1829 года (Письмо к Гречу). В: Северная пчела. № 103.

Букгарин, Ф.В. (1829b). Поездка из Аифмяндии в Самогитию, чрез Курмяндию, кетом 1829 года (Письмо к Гречу). В: Северная пчела. № 104.

Бумгарин, Ф.В. (1835). Путевые заметки на поезАке из Аерпта в Белоруссию и обратно, весною1835 года. В: Северная пчела. № 176.

Видок Финялрин. Письма и агентурные записки Ф.В. Булгарина в III отделение. (1998). Рейтблат, А.И. / Пубц., сост., предисл. и коммент. Москва: Новое китературное обозрение.

Гун, О. (1804). Топографическое описание города Риги с присовокуплением врачебных наблюдений. Ч. 1-2. Санкт-Петербург: Медицинская типография.

Иванова, Н.В. (2010). Жанр путевых записок в русской митературе первой трети XIX века (тематика, поэтика). Автореф. Аис. < .. > канА. филол. наук. Москва. 24 с.

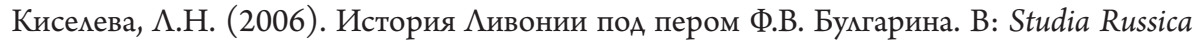
Helsingiensia et Tartuensia X: «Век нынешний и век минувший»: культурнал рефлексия прошедшей эпохи. В 2 ч. Тарту. Ч. 1. С. 114-127. Аоступен на 24.01.2016: http:// ruthenia.ru/document/541934.html

Михайлов, В.А. (1999). Эволючия жанра литературного путешествия в произведениях писателей XVIII-XIX веков. Автореф. Аис. <...> канА. филол. наук. Волгоград. 22 с.

Рейтблат, А.И. (2016). Переписка Н.И. Греча и Ф.В. Букгарина. В: Фаддей Венедиктович Булгарин: идеолог, журналист, консультант сыскной полиции. Статьи и материалы. Москва: Новое митературное обозрение. 632 с. 
Роболи, Т. (1926). Аитература «путешествий». В: Русская проза: Сборник статей. Эйхенбаум, Б., Тынянов, Ю. / реА. АенинграА: Academia. С. 42-73.

Топоров, В.Н. (1995). Петербург и «Петербургский текст русской митературы» (Введение в тему). В: Топоров, В.Н. Миф. Ритуал. Символ. Образ: Исследования в области мифопоэтического. Избранное. Москва: ИзАательская группа «Прогресс»-«Кумьтура». 624 с.

Kursìte, J., Sproge, L., Cimdina, A. (2008). Рига: образ и смысл. B: Rīgas teksts. Puжккий текст. Сборник научных материалов и статей. Рига: Latvijas Universitāte. 219 с.

\section{Rīgas teksts F. Bulgarina ceḷojuma aprakstā "Brauciens no Livonijas uz Samogitiju caur Kurzemi, 1829. gada vasara (vēstule Grečam)"}

Rakstā aplūkota Rīgas teksta specifika maz pētìtajā Fadeja Bulgarina ceļojuma aprakstā "Brauciens no Livonijas uz Samogitiju caur Kurzemi, 1829. gada vasara (vēstule Grečam)”. Raksta autore F. Bulgarina cel̦ojuma piezīmes pēta kā daudzfunkcionālu žanriski stilistisku veidojumu, atklājot Rīgas teksta producēšanas mehānismu (Vladimirs Toporovs). Rakstnieka ideja par apgaismības labvēlīgo ietekmi uz Baltijas galvaspilsètas materiālo dzīvi realizēta teksta struktūras un semantikas līmenī.

\section{The "Riga text" in "A trip from Liflandia to Samogitia, through Courland, in the summer of 1829 (The Letter to Grech)" by F.V. Bulgarin}

The article considers the specificity of the "Riga text" in the little-studied work "A trip from Liflandia to Samogitia, through Courland, in the summer of 1829 (The Letter to Grech)" by F.V. Bulgarin. The originality of the writer's "travel notes" is analysed as a multifunctional genre-style formation combining publicistic and literaryfiction components. about the research revealsthe existence of a "mechanism" that produces a movement from "the real to the real" (V. Toporov), which contributes to the application of the semiotic category "text" to the "travel" of Bulgarin. It is determined that the premises for the introduction of this work in scientific life are productive in terms of highlighting the "Riga text" in it, possessing the typical for the literary consciousness of the eighteenth and nineteenth centuries complex of features. The accentuation of the geopolitical, trade-economic, cultural and educational aspects of the "Riga text" expresses Bulgarin's idea of the beneficial influence of education on the spiritual and material life of the "Baltic capital" within the culture of everyday life, which occupies a priority place in the author's hierarchy of life values. 